\title{
PEDAGOGICAL CONDITIONS OF THE FORMATION OF THE INDIVIDUAL STYLE OF PROFESSIONAL ACTIVITY OF FUTURE PHYSICAL CULTURE TEACHERS IN THE PROCESS OF PEDAGOGICAL PRACTICE
}

\author{
Tetiana Bugaienko, \\ $\mathrm{PhD}$ in Pedagogy, Sumy State Pedagogical University named after A. S. Makarenko \\ http://orcid.org/0000-0003-3745-0593 \\ e-mail: bugaenkotv@ukr.net
}

\begin{abstract}
The scientific substantiation of the pedagogical conditions of the formation of the individual style of professional activity of future physical culture teachers in the process of pedagogical practice is outlined. This phenomenon is presented as a set of specially created circumstances that take into account the peculiarities of the professional training of future physical culture teachers and are realized in the institution of higher education; provide the solution of the problem, leading to innovative improvement of higher physical education. Internal positive motivation ensures encouraging attitude of students towards the development of an individual style of professional activity in the process of pedagogical practice and the improvement of the content of professional training - its content integrity. It has been found that the use of innovative technologies and techniques in the process of practical training contributes to the disclosure of individual and personal qualities, the development of cognitive and creative activity of future physical culture teachers in acquiring professional and pedagogical knowledge, skills and methods of healthcare-saving activity, determining their personal trajectory of professional growth. The development and implementation of a complex of searchsituational tasks enables the gradual formation of the individual style of professional activity of future physical culture teachers, develops their non-standard, non-stereotypical thinking and promotes self-development of their individuality in practical activity through the system of original methodical techniques of the organization of physical culture and health, sports-mass and health-development process in educational institutions.
\end{abstract}

Keywords: pedagogical conditions, individuality, an individual style of professional activity, a physical culture teacher, pedagogical practice.

Introduction. The implementation of a modern educational paradigm depends to a large extent on the teacher. The modern school needs teachers who embody a bright creative personality and can provide the maximum realization of the student's creative potential.

The Laws of Ukraine "On Higher Education" (2014), "On Education" (2017), the National Strategy for the Development of Education for the period up to 2021 (2013), the Pedagogical Constitution of Europe, the Concept of the New Ukrainian School (2017), the Sectoral Concept for the Development of Continuous Pedagogical Education (2013) refer to enhancing the role of the teacher in compelling students to study, stimulating their initiative and autonomy, socialization, preserving their health, forming a readiness for conscious life and professional choice. The implementation of these tasks is possible due to the introduction of new, progressive models of various forms and innovative methods and techniques of training and education. In this context the issue of improving the professional training of future physical culture teachers in institutions of higher education, in particular, the formation of an individual style of professional activity in the process of pedagogical practice is actualized.

The importance of studying this issue is due to: the need to improve the training of future physical culture 
teachers regarding their ability to form vital qualities of student youth, a stable motivation to study physical culture and sports against the background of decreased of physical activity; increase of the requirements for the professional activity of physical culture teachers, especially, regarding the organization of physical culture and health, sports-mass and healthdevelopment process in educational institutions, as well as professional development and self-realization in professional activity; an objective need for the search for innovative methods of training future physical culture teachers, in particular the formation of an individual style of professional activity in the process of pedagogical practice.

Materials and methods. Various aspects of the formation of the style of education, teaching, pedagogical leadership, pedagogical and professional activity have been studied by K. Abulkhanova-Slavska, O. Bodalov, N. Bordovska, L. Zimina, I. Zyazyun, Zh. Kovaliv, A. Markova, A. Rean and others. The study of the peculiarities of the individual style of activity have been carried out by C. Hilmanov, E. Klimov, V. Merlin, V. Nebylitsyn, A. Sannikova B. Teplov and others. The significance of pedagogical practice in the training of future teachers is disclosed in the works of Z. Abasov, M. Vorobyova, T. Mikhailova, L. Khomych and others. The thorough analysis of the professional training of future physical culture teachers has been performed by O. Azhippo, O. Atamas, E. Vilchkovsky, P. Dzhurinsky, M. Karchenko, T. Krusevich, Yu. Kurnyshev, M. Lyannoy L. Sushchenko, O. Tymoshenko, B. Shyyan and others.

However, the issue of substantiation of pedagogical conditions and ways of adjusting the existing individual style of professional activity (hereinafter ISPA) of future physical education teachers in the training, including the process of teaching practice, is insufficiently developed.

Research methods: theoretical analysis, comparison, generalization - with the aim of revealing and theoretical substantiation of the pedagogical conditions of the formation of the individual style of professional activity of future physical culture teachers in the process of pedagogical practice; the method of questioning and independent expert evaluation - to determine the most important pedagogical conditions.

The purpose of the research: to identify and scientifically substantiate the most effective pedagogical conditions of the formation of the individual style of professional activity of future physical culture teachers in the process of pedagogical practice.

Results and discussions. The pedagogical conditions of the formation of the professional qualities of future teachers are the subject of numerous scientific researches (Hrebenyuk O. and Hrebenyuk T., 2006; Tymoshenko 2008; Nychkalo, 2014; Radkevich, 2016; Kurnyshev, 2016; Bugaenko, 2018), but only a part of them takes into account the specifics of professional activity and peculiarities of educational training of the specialists of a particular branch.

The term "condition" is recognized a certain set of changing natural, social and internal actions that affect the physical, mental, moral development of a man, his behavior, education and training, the formation of personality (Dubasenyuk, 2006, p. 36). The derivative concept of the scientific category "condition" is the term "pedagogical conditions", the multiplicity of which is outlined by the numerous interpretations of scientists and projects a broad perspective for research. Some authors propose to consider them as external circumstances which ensure the functioning and development of a process that requires some sort of organization - (Karpychev, 2004). In other works the pedagogical conditions are positioned as external circumstances, factors that significantly influence the pedagogical process, designed by the teacher, as such that causes, but does not guarantee the desired results.

On this basis we consider the pedagogical conditions as a complex of means of effective implementation of the educational process; a set of objective possibilities of content, forms, methods, techniques, means of pedagogical activity. In determining the pedagogical conditions of the formation of the ISPA of future physical culture teachers in the process of pedagogical practice we take into account the essential characteristics of the investigated process and the requirements based on objectivity, systemacy, structuring, interdependence and specificity justified by methodologists.

The professional activity of physical culture teachers requires, on the one hand, the activation of individual properties and acquired professional qualities, and on the other hand - taking into account the objective professional qualification requirements. In this context we consider the arguments of the researchers that the pedagogical conditions determine the functioning of a special environment in which an individual style is formed, manifested and developed as a systemic personal formation, specified by a complex of intellectual, motivational, psychological properties and other qualities.

Studying and generalization of the scientific papers of N. Nychkalo, V. Radkevich, V. Rybalko, B. Semychenko, A. Tymoshenko, A. Tsosya, B. Shyyan and others testifies that internal and external factors are important in the formation of the individual style of future physical culture teachers. Among the internal factors the following are distinguished - personal qualities, individual peculiarities of the development of the psyche, the appearance of new formations in the existential, regulatory and emotional spheres, 
which ensure the development of active philosophical positions and aspirations of future physical culture teachers to the choice of an individually peculiar set of the components of activity (goals, actions, operations), which are most consistent with their personal qualities and enable the most successful implementation of the tasks provided by the program of pedagogical practice. The external factors determine the factors related to the formation and implementation of the relations between the teacher and students, the organization and objective evaluation of the educational process; the place of the study, subject environment, equipment and others (Hrebenyuk and Hrebeniuk, 2006).

The pedagogical conditions of the formation of the ISPA of future physical culture teachers are characterized by the original content, the essence of which reflects the integration specificity of the professional activity of such specialists in the organization of physical culture and health, sports-mass and health-development process in educational institutions, as well as professional development and self-realization of professional activity. Therefore, to clarify the pedagogical conditions of the formation of the ISPA of future physical culture teachers, in addition to theoretical analysis and generalization, a method of questioning and independent expert evaluation has been used, in which 30 physical culture teachers of higher educational institutions and 65 physical culture teachers have participated. Each of the respondents was asked to name the factors that had a positive impact on the formation of the ISPA. Of the total number of the respondents' responses, 15 of the most frequently repeated variants of the formulation of the conditions which were summarized and graphically presented in Table 1 were selected.

\section{Table 1}

The main factors influencing the formation of the individual style of professional activity of future physical culture teachers in the process of pedagogical practice (according to the survey results)

\begin{tabular}{|c|c|c|}
\hline $\begin{array}{l}\text { № } \\
\text { w/o }\end{array}$ & Generalized interpretative variants of the formulation of pedagogical conditions & $\begin{array}{l}\text { ency response } \\
\text { rate }\end{array}$ \\
\hline 1. & Accentuation of value-motivational, cognitive-content and operational-action activity & 3,4 \\
\hline 2. & $\begin{array}{l}\text { Encouraging future physical culture teachers to manifest their own potential in the process } \\
\text { of pedagogical practice in order to achieve success in further professional activity }\end{array}$ & 14,5 \\
\hline 3. & $\begin{array}{l}\text { Harmonization of individual needs of teachers, professional interests of students with request } \\
\text { of practice of physical education }\end{array}$ & 3,1 \\
\hline 4. & $\begin{array}{l}\text { Purposeful self-actualization of the personality of the future teacher based on self-determination, } \\
\text { self-development and the desire to develop an individual style of pedagogical activity }\end{array}$ & 3,2 \\
\hline 5. & $\begin{array}{l}\text { Deepening of knowledge of future physical culture teachers about the mechanisms and ways } \\
\text { of development of the ISPA on the basis of teaching special courses and variational educational } \\
\text { disciplines }\end{array}$ & 12,5 \\
\hline 6. & $\begin{array}{l}\text { Realization of the ideas of the individual approach in the educational and cognitive activity } \\
\text { of future physical culture teachers during pedagogical practice }\end{array}$ & 5,3 \\
\hline 7. & $\begin{array}{l}\text { The in-depth nature of practical activity provides the involvement of the students in the } \\
\text { implementation of all types of professional activity of the physical culture teachers during } \\
\text { the professional training process }\end{array}$ & 11,6 \\
\hline 8. & $\begin{array}{l}\text { The priority of independent work with ensuring the possibility of free choice of strategies, methods } \\
\text { and mechanisms for the implementation of individual plans and programs for professional activity } \\
\text { and professional self-improvement }\end{array}$ & 8,4 \\
\hline 9. & $\begin{array}{l}\text { Continuous diagnosis and correction of the state of the formation of an individual style } \\
\text { of professional activity }\end{array}$ & 3,2 \\
\hline 10. & $\begin{array}{l}\text { Psychological and pedagogical support of students' professional formation as individuals } \\
\text { in the process of pedagogical practice }\end{array}$ & 7,4 \\
\hline 11. & $\begin{array}{l}\text { Development and implementation of educational programs and algorithms for working out } \\
\text { the individual style of activity }\end{array}$ & 5,3 \\
\hline 12. & $\begin{array}{l}\text { The use of case studies and creative tasks with the possible gradual increase of the level of complexity } \\
\text { in the process of pedagogical practice }\end{array}$ & 6,3 \\
\hline 13. & $\begin{array}{l}\text { Methodical provision of practical implementation of the monitoring of the quality of the formation } \\
\text { of the individual style of professional activity }\end{array}$ & 4,2 \\
\hline 14. & $\begin{array}{l}\text { The use of various forms of organization of independent work of study with the purpose } \\
\text { of development of students' creative abilities }\end{array}$ & 5,3 \\
\hline 15. & Functioning of a favorable educational and developing environment & 6,3 \\
\hline
\end{tabular}


In order to determine the most important pedagogical conditions for the formation of ISPA of future physical culture teachers, the method of independent expert evaluation has been used, according to which the source of information is the results of quantitative and qualitative processing of evaluative judgments of the experts of a particular phenomenon or process. The main functions of this method of cognition are diagnostic, prognostic, planning, designing (Novosad compl., 2009). Seven scientists from the National Academy of Pedagogical Sciences of Ukraine, seven professors from the higher educational institutions, in which the future physical education teachers are being trained, as well as seven physical culture teachers, have formed an expert group on the evaluation of the importance of the pedagogical conditions of the formation of the ISPA of future physical culture teachers in the process of pedagogical practice.

The generalized results of the conducted independent evaluation with the calculation of the average score, the significance of the pedagogical condition, its final place of the indicator in the process of training future physical culture teachers is presented in Table 2.

As the pedagogical conditions for accentuation of value-motivational, cognitive-content and operationalaction activity, stimulation of future physical culture

Table 2

Pedagogical conditions of the formation of the individual style of professional activity of future physical culture teachers (on the basis of independent expert evaluation)

№ Pedagogical conditions of the formation of the individual style of professional w/o activity of future physical culture teachers

\begin{tabular}{ccc}
$\begin{array}{c}\text { Significance } \\
\text { of the } \\
\text { condition }\end{array}$ & $\begin{array}{c}\text { Average } \\
\text { score of the } \\
\text { condition }\end{array}$ & $\begin{array}{c}\text { Ranked } \\
\text { place }\end{array}$ \\
\hline & & \\
& &
\end{tabular}

1. Accentuation of cognitive-content, operational-activity, value-motivational activity

10,3

0,9

$12-15$

2. Encouraging of future physical culture teachers to manifest their own potential in the process of pedagogical practice in order to achieve success in further professional activity

1,0 8,6 1

3. Harmonization of individual needs of the teachers, professional interests of the students with requests of practice of physical education

9,6

1,1

4. Purposeful self-actualization of the personality of the future teacher based on self-determination, self-development and the desire to develop an individual style of pedagogical activity

9,8

1,6

5. Deepening of knowledge of future physical culture teachers about the mechanisms and ways of development of the ISPA on the basis of teaching special courses and variational educational disciplines

$8,3 \quad 2$

6. Realization of the ideas of the individual approach in the educational and cognitive activity of future physical culture teachers during pedagogical practice

9,1

$3,5-10$

7. The in-depth nature of practical activity, which provides the involvement of the students in the implementation of all types of professional activity of physical education teachers during the process of professional training

1,8

7,6

8. The priority of independent work with ensuring the possibility of free choice of the strategies, methods and mechanisms for the implementation of individual plans and programs for professional activity and professional self-improvement

9. Continuous diagnosis and correction of the state of the formation of an individual style of professional activity

3,6

4,9

4

10. Psychological and pedagogical support of the students' professional formation as individuals in the process of pedagogical practice

12,6 0,8

11. Development and implementation of educational programs and algorithms for working out the individual style of activity 5,1 4,4 5

2. The use of case studies and creative tasks with the possible gradual increase of the level of complexity in the process of pedagogical practice

8,6

$2,1 \quad 8-10$

13. Methodical provision of practical implementation of the monitoring of the quality of the formation of the individual style of professional activity

7,0

3,9

14. The use of various forms of organization of independent work of study with the purpose of development of students' creative abilities

9,4

1,7

11

15. Functioning of a favorable educational and developing environment

\begin{tabular}{ccc}
8,1 & 2,6 & $8-10$ \\
7,2 & 3,6 & $6-7$ \\
\hline
\end{tabular}


teachers to the manifestation of their own potential in the process of pedagogical practice in order to achieve success in further professional activity are inherently interrelated and provide for the coordination of the individual needs of the teachers, the professional interests of the students with the demands of practice of physical education, as well as focused on selfactualization through self-determination, selfdevelopment and the desire to develop an individual style of pedagogical activity, then the pedagogical conditions with sequence numbers 1, 2, 3, 4 (see Table 2) are united into one, which is reflected in such an interpretation of the first condition: the formation of internal positive motivation to the development of an individual style of professional activity.

The scientific basis for determining the mechanisms for implementing this condition was the principles of humanistic psychology and pedagogy, described in the work of K. Rogers (1959): "it is important for a person to have her/his own perception of the surrounding world; a person aspires to self-knowledge and selfrealization, he has an internal need for selfimprovement". The professional activity of future physical culture teachers in the process of pedagogical practice is determined by the following groups of motives for the formation of the ISPA: socially significant (the desire to acquire new knowledge, skills and abilities to grow professionally, and, therefore, to promote social progress); professionally significant (love for children, physical culture and sport, creative nature of professional activity); self-education and authority (positive image among the students, parents, colleagues, high professional ideals, the desire to stand out, express oneself, self-realization and self-assertion, expansion of outlook).

The realization of the condition must be oriented towards the formation of a positive attitude towards the development of an individual style of professional activity of future physical culture teachers in the process of pedagogical practice, which influences their activity, purposefulness and persistence in mastering theoretical knowledge, acquire professional skills and skills in the organization of physical culture and health, sports-mass and health-development process in educational institutions.

The main mechanisms to ensuring this condition are the methods and techniques for updating individual value-motivational, cognitive-content and operationalaction activity of the students regarding the assimilation of professional knowledge of the individual style of activity, professional development, the mechanisms of an individual style development and its manifestation in professional activity; acquisition and presentation of professional skills and skills in the organization of physical culture and health, sports-mass and health-development process in educational institutions, as well as critical thinking necessary for self-satisfaction in the profession, communicative interaction that occurs not only in teaching practice, but also during the training courses.

Continuous diagnosis and correction of the state of the formation of the individual style of professional activity of future physical culture teachers from the course to the course allows identifying and taking into account positive changes of the personal qualities that occur as a result of the external targeted effects in the conditions of specially created educational and developing environment. The empirical data obtained in the course of diagnosis make it possible to minimize the probable contradictions and mistakes in determining the levels of the formation of the ISPA. Referring to the results of the diagnosis allows revealing the qualities and characteristics of future physical culture teachers, on the development of which should work students and teachers.

During the pedagogical practice of future physical culture teachers, it is necessary to provide permanent psychological and pedagogical assistance in developing of an individual style of activity that would contribute to the successful implementation of professional tasks in the organization of physical culture and health, sports-mass and healthdevelopment process in educational institutions.

The content of psychological and pedagogical and methodological support is to provide students continuously with the assistance in solving their individual problems, identify, analyze critically and eliminate psychological barriers that complicate the interaction with the subjects of the educational process. In conducting the accompaniment it is important to adhere to the sequence in applying such techniques: approval, analysis of the errors and shortcomings, advice. Psychological and pedagogical help and stimulation of active actions of future physical culture teachers are considered as interrelated mechanisms of the formation of the individual style of professional activity. The purpose of stimulation is to create an atmosphere of creative learning of knowledge, the awakening of the desire to find new, the formation of the needs of the individual in the professional selfimprovement. We support B. Shyyan's view that the identification of the creative potential of future teachers takes place during the active pedagogical interaction with the students in the process of pedagogical practice, which is specified using the original methods and techniques of activity (Shyyan, 2001).

In this regard we have reasons to assert that psychological and pedagogical support in the situations of the subject-subject interaction, oriented on the formation of an individual style of professional activity, 
involves overcoming psychological barriers, promotes updating of value-motivational, cognitive-content and operational-action activity of practitioners, development of the positive feelings, the formation of own vision of the prospects for achievement professional success, beliefs about the correct choice of the style of professional activity.

The second pedagogical condition of the formation of the ISPA is indicated by the following formulation: improving the content of vocational training, taking into account the individualization of professional activity. In its content the pedagogical conditions with numbers 5, 6, 9, 11, which in their essence are oriented on the development of individuality and personal qualities of future physical education teachers, are integrated.

The practical realization of this condition is possible on the basis of the priority of subject-active and searchsituational approaches to the organization of professional training and, first of all, the pedagogical practice of future physical culture teachers. Thus, the mechanisms for creating this condition are determined by understanding and perception of the peculiarity of pedagogical practice, during which future physical culture teachers may be in different subject areas: "the subject of study" (supervises the professional activity of the working physical education teacher, explores his style of activity, acquaints himself with the perspective pedagogical experience, distinguishes the acceptable forms, methods, techniques of work); "the subject of teaching" (uses various methods and techniques for the organization of health-improving educational process, health-saving technologies - for the formation of vital qualities of student youth, a stable motivation to study physical culture and sports). These positions include the student's perception of himself, the characterization of his existential sphere as dominant (the ability to self-awareness, self-esteem, comparison with other people). A common feature of the position is the integral "I-concept" (I am a student, I am a future teacher, I am a teacher, I am a professional).

Improvement of the content of vocational training taking into account the individualization of professional activity enables the content integrity of the formation of the individual style of professional activity, in particular: awareness of the future physical culture teachers the importance of the individual style of professional activity for self-realization, knowledge of the style, its varieties and components, the mechanisms of implementation and adjustment, promotes the formation of the ability to apply the acquired knowledge for the successful accomplishment of the tasks in the leading activities, in particular, the organization of physical culture and health, sports-mass and health-development process in educational institutions, which contributes to the integral formation of spiritual and physical strength of student youth.

Awareness of the importance of the formation of the ISPA of physical culture teachers is the basis for wider use of the latest technologies (informational, project, problem and others) that are intended to enhance the educational and cognitive activity of the students, increase the efficiency of their general scientific and professional training and are taken into account in the formulation of the third pedagogical condition. By its very nature, the specified condition synthesizes the content of the terms with numbers 7 , 8, 10, 13, 14 (see Table 2).

The students' activity during the pedagogical practice is analogous to the professional work of the teacher, adequate to its content and structure, and is organized in the conditions of educational realities. In connection with this the motivating factor in the formation of the ISPA is the use of innovative techniques and technologies, in particular, conducting workshops, training sessions, discussions, the widespread use of interactive methods, namely: "method-press", "choose a position", "aquarium", "rotation triplets", "world cafe" and so on, which are described in details in a number of scientific works and methodical manuals. An important method of shaping the ISPA of future physical culture teachers is the research. Within the framework of its application students will be provided with mini-studies related to the study of the peculiarity of the professional activity of physical culture teachers and their stylistic manifestations and the compilation of the interpretive characteristics of the ISPA. Based on the application of the method, in the minds of future teachers the belief is formed that an effective individual style provides the greatest result at the minimum time and effort, as well as the fact that the formation of their own style, taking into account, first of all, the properties of the person itself, as well as the specifics of the requirements of activity contributes to the increase of productivity. At the same time a stable idea of the possibility of developing the ISPA is formed.

In order to optimize the methodological support of the formation of the ISPA of future physical culture teachers, it is important to carry out pedagogical quality monitoring. The implementation of the condition involves the use of a multi-level system of forwardlooking improvement of pedagogical skills, which would take into account the conditions of the institutions of higher education, would be based on the capabilities, abilities and characteristics of each student-practitioner. The creation of such a system involves the changes in the organization of pedagogical practice in order to enhance the individuality and 
practical orientation of the professional training of future physical culture teachers from the first to the last year of study. Such an approach is innovative in the training of future physical culture teachers, and therefore, in pedagogical practice as well. It is desirable that every student-practitioner, every physical culture teacher should appreciate positively, first of all, their personal qualities and capabilities and should define their own social role in the overall innovation process.

The fourth condition theoretically and methodologically grounded is the development and implementation of a complex of search and situational tasks, oriented towards the gradual formation of the individual style of professional activity of future physical culture teachers; involves the development of creative critical thinking, promotes selfdevelopment of a person's individuality in practical activity through the system of original methods of the organization of physical culture and health, sports-mass and health-development process in educational institutions. The need for solving such problems arises in certain pedagogical situations, which makes it possible to increase gradually their complexity in the process of pedagogical practice and, consequently, the gradual formation of the ISPA.

The provision of student-practitioners with a complex of search-situational tasks with a gradual increase of the level of their complexity in the process of pedagogical practice is conditioned by the absence of objective circumstances in the real educational space for the manifestation of the students' individuality. In the process of performing such tasks, students have the opportunity to choose their own individual way of pedagogical interaction, which will help to identify their own personality, manifestation of creativity and determination of the personal trajectory of professional growth.

Conclusions. The pedagogical conditions of the formation of an individual style are a set of specially created circumstances that take into account the peculiarities of the professional training of future physical culture teachers and are implemented in the institution of higher education; provide a solution to the scientific problem, leading to the innovative improvement of higher physical education. It is proved that the formation of the students' internal positive motivation provides a positive attitude towards the development of an individual style of professional activity in the process of pedagogical practice, affects their activity, purposefulness and persistence in mastering theoretical knowledge, acquiring professional skills and skills in the organization of physical culture and health, sports-mass and healthdevelopment process in educational institutions. Improvement of the content of vocational training taking into account the individualization of professional activity enables the content integrity of the formation of an individual style of professional activity, in particular: awareness of the future physical culture teachers the importance of the individual style of professional activity for self-realization, knowledge of the style, its varieties and components, the mechanisms of implementation and updating, promotes the formation of the ability to apply the acquired knowledge for the successful accomplishment of the tasks in the leading activities, in particular the organization of physical culture and health, sports-mass and health-development process in educational institutions, which contributes to the integral formation of the spiritual and physical strength of student youth. It has been found that the use of innovative technologies and techniques in the process of practical training contributes to the disclosure of individual and personal qualities, the development of cognitive and creative activity of future physical culture teachers in acquiring professional and pedagogical knowledge, skills and methods of healthcare-saving activity, determining their personal trajectory of professional growth. The development and implementation of a complex of search-situational tasks enables the gradual formation of the individual style of professional activity of future physical culture teachers, develops their non-standard, non-stereotypical thinking and promotes self-development of their individuality in practical activity through the system of original methodical techniques of the organization of physical culture and health, sports-mass and healthdevelopment process in educational institutions.

\section{List of references}

Бугаєнко, Т., 2018. Індивідуальність і стиль учителя фізичної культури. Суми: Цьома С. П.

Гребенюк, О. та Гребенюк, Т., 2006. Основы педагогики индивидуальности. Калининград.

Карпичев, В. 2004. Организация и самоорганизация социальних систем. 2-е изд. М.: Изд-во РАГС.

Новосад, В. П. уклад., 2009. Кількісні методи експертного очінювання, Київ: НАДУ.

Курнишев, Ю., 2016. Проблема професійного саморозвитку вчителя фізичної культури у педагогічній культурі і практиці. ScienceRise, V. 1, 5(18). URL: http://journals.uran.ua/sciencerise/article/ view/59146.

Дубасенюк, О., уклад., 2006. Професійно-педагогічна освіта: сучасні концептуальні моделі та тендениіїрозвитку. Житомир: ЖДУ ім. І. Франка. 
Ничкало, Н., 2014. Розвиток професійної освіти в умовах глобалізаційних та інтеграційних процессів: Київ: Вид-во НПУ ім. М. П. Драгоманова.

Радкевич, В., 2016. Теоретичні та методичні засади розвитку професійної освіти і навчання: результати, проблеми, перспективи. Науковий вісник Інституту професійно-технічної освіти НАПН Украӥни. Професійна педагогіка, 11, c. $5-22$.

Тимошенко, О., 2008. Оптимізація професійної підготовки майбутніх учителів фізичної культури: Київ, Видво НПУ ім. М.П. Драгоманова.

Шиян, Б., 2001. Підготовка вчителя фізичної культури третього тисячоліття. Концепщія розвитку галузі фізичного виховання і спорту в Україні, 2, с. 371-374.

Rogers, C., 1959. A Theory of Therapy, Personality and Interpersonal Relationship, As Developed in The Client-Centered Framework. Psychology: A Study of a Science, 3. p. 134-256.

\section{Translated \& Transliterated}

Buhaienko, T., 2018. Indyvidualnist $i$ styl uchytelia fizychnoi kultury [Individuality and the style of the physical culture teacher]. Sumy: Tsoma S. P., [in Ukrainian].

Grebenyuk, O. ta Grebenyuk, T., 2006. Osnovyi pedagogiki individualnosti [Basics of pedagogy of individuality]. Kaliningrad: b.v., [in Ukrainian].

Karpychev, V., 2004. Orhanyzatsyia y samoorhanyzatsyia sotsyalnykh system [Organization and self-organization of social systems]. 2-e yzd. M. : Yzd-vo RAHS, [in Russia].

Novosad, V. P., uklad., 2009. Kilkisni metody ekspertnoho otsiniuvannia [Quantitative methods of evaluation], Kyiv: NADU, [in Ukrainian].

Kurnyshev, Yu., 2016. Problema profesiinoho samorozvytku vchytelia fizychnoi kultury u pedahohichnii kulturi i praktytsi [The problem of professional self-development of a physical culture teacher in pedagogical culture and practice] ScienceRise, [online] 1, 5(18). Dostupno: < http://journals.uran.ua/sciencerise/article/ view/59146> [Data zvernennia 05 Kviten 2019], [in Ukrainian].

Dubaseniuk, O., uklad., 2006. Profesiino-pedahohichna osvita: suchasni kontseptualni modeli ta tendentsii rozvytku [Professional-pedagogical education: contemporary conceptual models and trends]. Zhytomyr: ZhDU im. I. Franka, [in Ukrainian].

Nychkalo, N., 2014. Rozvytok profesiinoi osvity v umovakh hlobalizatsiinykh ta intehratsiinykh protsesiv [Development of vocational education in the conditions of globalization and integration processes]. Kyiv: Vyd-vo NPU im. M. P. Drahomanova, [in Ukrainian].

Radkevych, V., 2016. Teoretychni ta metodychni zasady rozvytku profesiinoi osvity i navchannia: rezultaty, problemy, perspektyvy [Theoretical and methodological foundations of the development of vocational education and training: results, problems, perspectives]. Naukovyi visnyk Instytutu profesiino-tekhnichnoi osvity NAPN Ukrainy [Scientific herald of the Institute of vocational education and training of NAES of Ukraine. Professional Pedagogy], 11, s. 5-22, [in Ukrainian].

Tymoshenko, O., 2008. Optymizatsiia profesiinoi pidhotovky maibutnikh uchyteliv fizychnoi kultury [Optimization of professional training of future physical culture teachers]. Kyiv: Vyd-vo NPU im. M.P. Drahomanova, [in Ukrainian].

Shyian, B., 2001. Pidhotovka vchytelia fizychnoi kultury tretoho tysiacholittia [Training teachers of physical culture of the third millennium]. Kontseptsiia rozvytku haluzi fizychnoho vykhovannia i sportu v Ukraini [The concept of physical education and sport in Ukraine], 2, s. 371-374, [in Ukrainian].

Rogers, C., 1959. A Theory of Therapy, Personality and Interpersonal Relationship, As Developed in The Client-Centered Framework. Psychology: A Study of a Science, 3. p. 134-256, [in English].

УДК 378.147-027.22:[37.011.3-051:796

\section{Педагогічні умови формування індивідуального стилю професійної діяльності майбутніх учителів фізичної культури у процесі педагогічної практики}

\section{Тетяна Бугаєнко,}

кандидат педагогічних наук, Сумський державний педагогічний університет імені А. С. Макаренка

Реферат. Викладено наукове обгрунтування педагогічних умов формування індивідуального стилю професійної діяльності (далі: ІСПД) майбутніх учителів фізичної культури у процесі педагогічної практики. Цей феномен представлено як сукупність спеціально створених обставин, що враховують особливості професійної підготовки майбутніх учителів фізичної культури та реалізуються в умовах закладу вищої освіти, забезпечують розв'язання поставленої проблеми, зумовлюючи інноваційне вдосконалення вищої фізкультурної освіти. Внутрішня позити- 
вна мотивація забезпечує позитивне ставлення студентів до вироблення індивідуального стилю професійної діяльності у процесі педагогічної практики, а вдосконалення змісту професійної підготовки - його змістову цілісність. 3'ясовано, що використання інноваційних технологій і методик у процесі практичної підготовки сприяє розкриттю індивідуально-особистісних якостей, розвитку пізнавальної та творчої активності майбутніх учителів фізичної культури в набутті професійно-педагогічних знань, умінь і способів здоров'язбережувальної діяльності, визначенню ними особистісної траєкторії професійного зростання. Розроблення та впровадження комплексу пошуково-ситуативних завдань уможливлює поетапне формування індивідуального стилю професійної діяльності майбутніх учителів фізичної культури, розвиває в них нестандартність, нестереотипність мислення, сприяє самопрояву їхньої індивідуальності у практичній діяльності через систему оригінальних методичних прийомів організації фізкультурно-оздоровчого, спортивно-масового й оздоровчо-розвивального процесу в закладах освіти.

Ключові слова: педагогічні умови, індивідуальність, індивідуальний стиль професійної діяльності, вчитель фізичної культури, педагогічна практика.

Received: 28 April 2019

Accepted: 24 May 2019 